\title{
Apoptosis Induction in Primary Human Colorectal Cancer Cell Lines and Retarded Tumor Growth in SCID Mice by Sulforaphane
}

\author{
Ming-Jenn Chen,, ${ }^{1}$ Wei-Yu Tang, ${ }^{2}$ Che-Wei Hsu, ${ }^{3}$ Ya-Ting Tsai, ${ }^{2}$ June-Fu Wu, ${ }^{3}$ Chen-Wei Lin, ${ }^{3}$ \\ Ya-Min Cheng, ${ }^{4}$ and Yi-Chiang $\mathrm{Hsu}^{2,5}$ \\ ${ }^{1}$ Division of Traumatology, Department of Surgery, Chi Mei Medical Center, Tainan, Taiwan \\ ${ }^{2}$ Graduate Institute of Medical Science, College of Health Sciences, Chang Jung Christian University, No. 396, Sec. 1, Changrong Road, \\ Gueiren District, Tainan City 71101, Taiwan \\ ${ }^{3}$ Department of Nutrition and Health Sciences, College of Health Sciences, Chang Jung Christian University, No. 396, Sec. 1, Changrong \\ Road, Gueiren District, Tainan City 71101, Taiwan \\ ${ }^{4}$ Department of Obstetrics and Gynecology, Institute of Clinical Medicine, College of Medicine, National Cheng Kung University, \\ Tainan, Taiwan \\ ${ }^{5}$ Innovative Research Center of Medicine, College of Health Sciences, Chang Jung Christian University, No. 396, Sec. 1, Changrong Road, \\ Gueiren District, Tainan City 71101, Taiwan
}

Correspondence should be addressed to Yi-Chiang Hsu, jenway@mail.cjcu.edu.tw

Received 20 January 2011; Revised 28 April 2011; Accepted 2 May 2011

Academic Editor: Jae Youl Cho

Copyright (C) 2012 Ming-Jenn Chen et al. This is an open access article distributed under the Creative Commons Attribution License, which permits unrestricted use, distribution, and reproduction in any medium, provided the original work is properly cited.

\begin{abstract}
We have investigated the anticancer effects of the dietary isothiocyanate sulforaphane (SFN) on colorectal cancer (CRC), using primary cancer cells lines isolated from five Taiwanese colorectal cancer patients as the model for colorectal cancer. SFN-treated cells accumulated in metaphase (SFN $6.25 \mu \mathrm{M}$ ) and subG1 (SFN 12.5 and $25 \mu \mathrm{M}$ ) as determined by flow cytometry. In addition, treated cells showed nuclear apoptotic morphology that coincided with an activation of caspase-3, and loss of mitochondrial membrane potential $(\Delta \Psi \mathrm{m})$. Incubations at higher SFN doses $(12.5$ and $25 \mu \mathrm{M})$ resulted in cleavage of procaspase-3 and elevated caspase-2, $-3,-8$, and -9 activity, suggesting that the induction of apoptosis and the sulforaphane-induced mitosis delay at the lower dose are independently regulated. Daily SFN s.c. injections ( 400 micromol $/ \mathrm{kg} / \mathrm{d}$ for 3 weeks) in severe combined immunodeficient mice with primary human CRC (CP1 to CP5) s.c. tumors resulted in a decrease of mean tumor weight by $70 \%$ compared with vehicle-treated controls. Our findings suggest that, in addition to the known effects on cancer prevention, sulforaphane may have antitumor activity in established colorectal cancer.
\end{abstract}

\section{Introduction}

Isothiocyanates (ITCs) are natural components of certain plants and vegetables that have selective biological activities and functions against carcinogenesis $[1,2]$, and many chemopreventive properties have been reported [3, $4]$. The use of naturally occurring compounds combined with chemotherapy might enhance drug sensitivity $[5,6]$. Sulforaphane (SFN), a potent cancer preventive agent, is a dietary isothiocyanate compound found as a precursor glucosinolate in cruciferous vegetables such as Brussels sprouts, cauliflower, and broccoli [7]. Interest in this agent has grown in recent years based on its putative beneficial pharmacological effects, which include antioxidant [8], antiinflammatory [9], and antitumor properties [10, 11]. It has been discovered that SFN is also a potent scavenger of reactive oxygen species (ROS), including superoxide anions and hydroxyl radicals $[12,13]$. Moreover, there have been some indications that SFN may help in the prevention and treatment of patients with oxidative damage and suppress the specific inflammatory factors $[14,15]$. Many studies indicate a positive correlation between the consumption of cruciferous vegetables and the decreased incidence of some tumors including prostate [16], cervical 
[17], ovarian [18], lung [19], and gastrointestinal tract [20, $21]$. In addition to the actions of inhibiting cell proliferation and increasing apoptosis [22], other mechanisms have also been proposed to rationalize the anticarcinogenic effect of SFN, such as the anti-inflammatory and antioxidant activities, the induction of phase-II detoxification enzymes, the inhibition of cyclooxygenase 2 (COX-2) [23], the effect on NF $\kappa$ B transcription factors [24], the inhibition of matrix metalloproteinase (MMP), the effect on protein kinases, and others $[25,26]$.

Effects of SFN on five established human primary cell lines (CP1 to CP5) were investigated in this study. In this paper, studies have been initiated to investigate whether the SFN could contribute to the antiproliferation and apoptosis of the primary cancer cells isolated from the colorectal cancer patients. The aims are to investigate whether the antiproliferation and apoptosis activities of SFN on the primary colon cancer cells could be explained. We expect that all of these experiments could provide a scientific basis and technical support for CRC therapy.

\section{Materials and Methods}

2.1. Materials. Sulforaphane [1-isothiocyanato- $(4 R, \mathrm{~S})$ (methylsulfinyl)butane], DMSO (dimethyl sulfoxide), and MTT [3-(4,5-dimethylthiazol-2-yl)-2,5-diphenyltetrazolium bromide] were obtained from Sigma (St. Louis, MO). Cell culture medium (DMEM), fetal bovine serum, antibiotics, sodium pyruvate, trypsin, and phosphate-buffered saline (PBS) were purchased from Gibco, BRL (Grand Island, NY). Polyvinylidene fluoride membrane (PVDF) (Millipore) and molecular weight markers were purchased from Bio-Rad (USA). All other reagents and compounds were analytical grades.

2.2. Cell Culture. The five primary cell lines of colon cancer cells were derived, as a gift, from the cell bank maintained in the MedicoGenomics Research Center at $\operatorname{KMU}[27,28]$. The cells were grown at $37^{\circ} \mathrm{C}$ in Dulbecco's Modified Eagle Medium (GibcoBRL) supplemented with 10\% (v/v) Fetal Bovine Serum (HyClone) and a combination of antibiotics (penicillin, $200 \mathrm{unit} / \mathrm{mL}$, and streptomycin, $200 \mathrm{~g} / \mathrm{mL}$ ) (HyClone) under an atmosphere $\mathrm{CO}_{2} /$ air $(5 \%)$ this series of studies.

2.3. Cell Proliferation Assay. The cells were seeded into 96well culture plates at 5000 cells/well. The cells were treated with $0,6.25,12.5,25$, and $50 \mu \mathrm{M}$ SFN for 1 to 4 days. MTT dye $(1 \mathrm{mg} / \mathrm{mL})$ was added to each well for at least 4 hours of treatment. The reaction was stopped by the addition of DMSO, and optical density was measured at $540 \mathrm{~nm}$ on a multiwell plate reader. Background absorbance of the medium in the absence of cells was subtracted. All samples were assayed in triplicate, and the mean for each experiment was calculated. Results were expressed as a percentage of control, which was considered as $100 \%$. Each assay was carried out in triplicate, and the results were expressed as the mean $( \pm$ SEM $)$.
2.4. Cell Cycle Analysis. The method for cell cycle analysis using propidium iodide (PI) is using the fluorescent nucleic acid dye PI to identify the proportion of cells that are in one of the three interphase stages of the cell cycle. The cells were treated with $0,6.25,12.5$, and $25 \mu \mathrm{M}$ SFN for 24 hours. Cells were harvested and fixed in $1 \mathrm{~mL}$ cold $70 \%$ ethanol at least 8 hours at $-20^{\circ} \mathrm{C}$. DNA was stained in PI/RNaseA solution, and the cell cycle (At least 10,000 single cells) was detected by flow cytometry (FACSCalibur, BD). Data was analyzed by WinMDI 2.8 free software (BD, USA).

2.5. Evaluation of Apoptosis. The apoptosis was assessed by the ApopNexin FITC apoptosis detection kit (Chemicon, USA). The cells were treated with $0,6.25,12.5$, and $25 \mu \mathrm{M}$ SFN for 6 hours, and the apoptotic cells were detected by ApopNexin FITC apoptosis detection kit and flow cytometry (FACSCalibur, BD) and data analyzed by WinMDI 2.8 free software (BD, USA).

2.6. Evaluation of Mitochondrial Membrane Potential (MMP; $\Delta \Psi m$ ). The cells were first seeded in 24-well plates (Orange, UK). Following the treatment with SFN for 6 hours, JC-1 $(10 \mu \mathrm{g} / \mathrm{mL}$, Sigma, USA $)$ was added to the culture medium, $50 \mu \mathrm{L}$ per well, and then incubated (at $37^{\circ} \mathrm{C}$ for $20 \mathrm{~min}$ ) for mitochondria staining. After washing twice with a warm PBS, the cells were fixed with $2 \%$ paraformaldehyde, inspected by Flow cytometry (FACSCalibur, BD) and data analyzed by WinMDI 2.8 free software (BD, USA).

2.7. Western Blot Assay. A total of $30-50 \mu \mathrm{g}$ proteins were separated by SDS-PAGE (10-12\% SDS-polyacrylamide gel electrophoresis) and transferred to PVDF membranes (Millipore, USA) in a tank blotter (in $25 \mathrm{mM}$ Tris/ $/ .192 \mathrm{M}$ glycine, $\mathrm{pH} 8.3 / 20 \%$ methanol) at 30 voltage overnight. The membranes were blocked with 5\% nonfat milk (in $10 \mathrm{mM}$ Tris- $\mathrm{HCl}, \mathrm{pH} 8.0 / 150 \mathrm{mM} \mathrm{NaCl} / 0.05 \%$ tween-20) overnight and incubated with anti- $\beta$-actin (AC-15 Sigma, USA), anti-Caspase 3 (SC-7148 Santa Cruz, USA) antibody for $1.5 \sim 2$ hours. The blots were washed with Tris- $\mathrm{HCl}(\mathrm{pH}$ $8.0 / 150 \mathrm{mM} \mathrm{NaCl} / 0.05 \%$ Tween-20) for $3 \times 10$ minutes and incubated with second antibody (antirabbit or antimouse immunoglobulins) (IRDye Li-COR, USA) at 1/200 dilution for 1 hour. The antigen was then visualized and analyzed by Odyssey infrared imaging system (Odyssey LI-COR, USA).

2.8. Caspase Activity Assay. The caspase (2-, 3-, 8-, and 9-) activity was assessed by the ApoAlert Caspase assay plates (Clontech, USA). The cells were treated with SFN of $0,12.5$, and $25 \mu \mathrm{M}$ with or without caspase-specific inhibitor for 8 hours. The caspase activity was detected by ApoAlert Caspase assay plates and inspected by the BioTek FLx800 TBI reader (Bio-Tek, USA). The plates contained the fluorogenic substrates and inhibitors specific for different caspases. These substrates were covalently linked to their respective activated caspases. The substrates were covalently linked to the fluorogenic dye 7-amino-4- 
methyl coumarin (AMC). Peptide-bound AMC excites in the UV range $(380 \mathrm{~nm})$ and emits at $460 \mathrm{~nm}$. The AMC was normalized by total protein, and each assay was carried out in triplicate, and the results were expressed as the mean $( \pm$ SEM).

2.9. Confocal Microscopy of NF- $\kappa B$ Subunit p50 Activity. Confocal microscopy was performed as described previously. Briefly, the CRC cells $\left(2 \times 10^{6}\right.$ cells $)$ were treated with 0 and $25 \mu \mathrm{M}$ SFN for 16 hours and were fixed on coverslips. After treatment, they were incubated with rabbit antihuman p50 antibody (SC-8414 PE, Santa Cruz Biotechnology) for 30 minutes and then washed with PBS. The cells were mounted onto microscope slides using mounting medium containing DAPI.

2.10. DNA Fragmentation Assay. The DNA fragmentation was detected by ApoAlert DNA fragmentation assay kit (Clontech, USA). The assay is based on terminal deoxynucleotidyl transferase-(TdT-) mediated dUTP nick end labeling (TUNEL). TdT catalyzes incorporation of fluoresceindUTP at the free $3^{\prime}$-hydroxyl ends of fragmented DNA. The cells were treated with SFN for 24 hours, and the fluoresceinlabeled DNA was detected via flow cytometry (FACSCalibur, BD, USA) and data analyzed by WinMDI 2.8 free software (BD, USA).

2.11. Tumor Xenograft Animal Model. Experiments were done on male severe combined immunodeficient (SCID) mice (National Laboratory Animal Center, Taipei, Taiwan) according to the regulation of the Institutional Animal Care and Use Committee (IACUC, CJCU-98-006). CRC (CP1 to CP5) tumors for implantation were initially grown from injections of CRC cell lines $\left(200 \mu \mathrm{L}\right.$ of $3 \times 10^{6}$ cells $)$ at the s.c. abdomen site. Tumor cells were implanted at the same site into an experimental animal at the age of 6 weeks. After 21 days of tumor establishment in severe combined immunodeficient mice, at the start of the exponential tumor growth phase, animals were randomly divided into the treatment groups $(n=3)$. Each animal received i.p. injection $(200 \mu \mathrm{L})$ either PBS (vehicle control) or SFN $(200 \mu \mathrm{M}$ and $400 \mu \mathrm{M}$ ) daily, including weekends, for 3 weeks. Animal body weight and tumor size were measured and recorded. Results were expressed as a percentage of vehicle control, which was considered as $100 \%$. Each assay was carried out in triplicate, and the results were expressed as the mean $( \pm$ SEM).

2.12. Statistical Analysis. All data were reported as the means $( \pm$ SEM) of at least three separate experiments. Statistical analysis was using $t$-test, with the significant differences determined at the level of $P<0.05$.

\section{Results}

3.1. SFN Inhibits the Cell Survival/Proliferation of Five Primary CRC Cell Lines. We hypothesized that SFN could mediate the survival of primary colorectal cancer cell lines and thus inhibit their proliferation. To explore this antitumor activity of SFN against the CRC cells, an in vitro study was initiated by treating each of the CRC cell lines to increasing doses of SFN $(0,6.25,12.5,25$, and $50 \mu \mathrm{M})$ for 24 hours. The proliferation of these SFN-treated cancer cells was then measured by MTT method. The results summarized in Figure 1(a) indicate that the survival and proliferation of the primary colon cancer cells both decrease per increase of the dose of SFN added into the cell culture, which show a dose-dependent reduction $\left(y=-12.3 x+114.65 R^{2}=\right.$ $0.9892)$. Moreover, SFN was noted to induce a morphological change in the primary colon cancer cells. A microscopic examination showed that following the exposure to SFN $(25 \mu \mathrm{M})$ for 6 to 24 hours, the primary colon cancer cells have displayed a remarkable change in their morphology and SFN induced the death of cancer cells, which formed a suspension in the medium (data not shown).

\subsection{Growth-Inhibitory Effect of SFN Is Partially Irreversible.} To study whether the growth-inhibitory effect of SFN is reversible, the primary colon cancer cells were recultivated in a fresh culture medium, after their exposure to SFN $(12.5 \mu \mathrm{M})$ for 24 hours, and the recovery of cell proliferation was then assessed for an additional 24 to 72 hours and analyzed by the MTT assay. The results in Figure 1(b) suggest that the cancer cells have substantially lost their ability to proliferate $\left(y=-18.495 x+112.83 R^{2}=0.9393\right)$ following the SFN treatment for 24 hours. The observations could imply that the primary colorectal cancer cells have undergone an irreversible change, such as apoptosis, at least to a partial extent.

3.3. Sulforaphane Inhibits Colony Formation in Human CRC Cells. We next examined the effects of SFN on colony formation (a characteristic of cancer) on five CRC cell lines by soft agar assay. SFN inhibited colony formation in a dosedependent manner (Figure 1(c)). Colonies formed by CRC cells were sensitive to SFN. These data suggest that SFN can be used as a potent chemopreventive agent for CRC therapy.

3.4. SFN Treatment Induces Cell Cycle G2/M Arrest and Accumulated Sub G1 in CRC Cell Lines. Cell cycle distribution of SFN-treated CRC cell lines was analyzed by flow cytometry, aiming to determine whether the inhibitory effect was due to cell cycle arrest and apoptosis. Before being processed and analyzed, both kinds of cells were exposed to SFN for a total of $24 \mathrm{~h}$. As shown in Figure 2(a), the CRC cells exposed to SFN $6.25 \mu \mathrm{M}$ showed G2/M arrest, but SFN 12.5 and $25 \mu \mathrm{M}$ showed increase in the number of cells in the sub G0/G1 phase, as compared with that of the untreated cells. These results revealed that SFN could hold up CRC cell line proliferation via caused cell cycle arrest in the G2/M phase and a significant increase in the proportion of cells in the sub G0/G1 phase. The results in Figure 2(b) suggest that the five CRC cell lines have accumulated sub G0/G1 phase $\left(y=11.602 x-12.985 R^{2}=0.9139\right)$ following the SFN 
treatment for 24 hours. The observations could imply that the primary colorectal cancer cells have undergone apoptosis.

\subsection{Apoptosis of CRC Cell Lines Induced by SFN. Detection} between the intact cells, early apoptotic cells, and late apoptotic cells or dead cells could be carried out with PIannexin- $\mathrm{V}$ double staining; thus, we performed this assay to further explore cell apoptosis. To explore the potential role that SFN could play in the apoptosis of CRC cells, the ApopNexin FITC apoptosis detection kit has been used to identify the formation of apoptotic cells in the five CRC cell lines after the 6 hours of exposure to SFN. A typical set of results for the ApopNexin FITC apoptosis detection kit is illustrated in Figure 3(a), in which the annexin V-FITC deposits are indicative of the positive existence of apoptotic cells. A dose-dependent increase in apoptosis was observed $\left(y=17.62 x-14 R^{2}=0.9654\right)$, that is, the higher the dose of $\operatorname{SFN}(6.25,12.5$ and $25 \mu \mathrm{M})$ used in the exposure, the greater the extent of apoptosis (Figure $3(\mathrm{~b})$ ). The increase of the percentages of apoptotic CRC cell lines was observed in all the doses after treatment for $6 \mathrm{~h}$. In $6 \mathrm{~h}$, approximately $4.6+0.6 \%$ of five CRC cells were totally apoptotic (early apoptosis and late apoptosis) cells in control. The rate of apoptotic CRC cells increased to $22.9+6.5 \%$ with $6.25 \mu \mathrm{M}$ SFN treatments. When the concentrations of SFN increased to 12.5 and $25 \mu \mathrm{M}$, the percentages of total apoptotic CRC cells increased to $32.6+8.9 \%$ and $60.1+21.3 \%$, respectively. Taken together, the observations imply that the apoptosis of CRC cell lines is significantly elevated by SFN.

3.6. Assessment of Changes in Mitochondrial Membrane Potential. The loss of mitochondrial membrane potential is a hallmark for apoptosis. It is an early event coinciding with caspase activation. In nonapoptotic cells, JC-1 exists as a monomer in the cytosol (green) and accumulates as aggregates in the mitochondria, which appear red. In apoptotic and necrotic cells, JC-1 exists in monomeric form and stains the cytosol green. Figure 4(a) shows typical FL1/FL-2 dot plots for JC-1 staining CRC cell lines with and without apoptosis. SFN-free CRC cell lines are without apoptosis, which have red fluorescing J-aggregates. The green fluorescing monomers shown in the lower part indicate apoptotic cell lines (SFN 6.25, 12.5, and $25 \mu \mathrm{M}$ treatment). Figure 4(b) shows the percentages of apoptotic CRC cell lines analyzed by flow cytometer in different SFN-treated groups. The $\mathrm{x}$-fold increase of mitochondrial membrane potential lost was observed in all the doses after treatment for $6 \mathrm{~h}$. In $6 \mathrm{~h}$, the folds increased to $1.8+0.6$ with $6.25 \mu \mathrm{M} \mathrm{SFN}$ treatment. When the concentrations of SFN increased to 12.5 and $25 \mu \mathrm{M}$, the folds raised to $2.3+0.9$ and $3.5+$ 0.5 , respectively. Taken together, the observations imply that SFN has significantly reduced the mitochondrial membrane potential of CRC cell lines.

3.7. SFN Inhibits Nuclear NF- $\kappa B$ Transcription Factor Activity in CRC Cell Lines. With finding functional changes and increased apoptosis of SFN in CRC cell lines, the NF- $\kappa \mathrm{B}$ activity of SFN-treated CRC cell lines was examined. NF$\kappa \mathrm{B}$ is a transcription factor regulating $\mathrm{DC}$ function and apoptosis. NF- $\kappa \mathrm{B}$ is inactive in the cytoplasm, as it binds to the protein inhibitor $\mathrm{I} \kappa \mathrm{B}$. Following the degradation of $\mathrm{I} \kappa \mathrm{B}$, NF- $\kappa \mathrm{B}$ p50/52 translocates into the nucleus and binds to its specific target DNA sequence. To explore the potential role that SFN inhibits nuclear NF- $\kappa$ B transcription factor activity of CRC cell lines, confocal microscopy was used to identify the activity of NF- $\kappa \mathrm{B}$ transcription factor in the CRC cell lines after the 16 hours of exposure to SFN. The results summarized in Figure 5 indicate that less NF- $\kappa \mathrm{B}$ subunit p50/52 was observed in the nuclei of CRC cell lines treated with SFN $25 \mu \mathrm{M}$ than in the nuclei of SFN-free CRC cell lines. This could imply that the primary colorectal cancer cell lines have repressed activity of NF- $\kappa \mathrm{B}$ as per increasing the dose of SFN added into the cell cultures.

3.8. Apoptosis Induction by SFN in CRC Cell Lines via Caspase Activation. Figure 6(a) shows the immunoblotting of cellular proteins from five CRC cell lines treated with SFN showing decrease of procaspase-3 after SFN incubation. Quantification of procaspase-3, done by measuring the relative band intensities, showed that procaspase-3 levels were significantly lower in cells incubated with SFN (Figure 6(b)). The results indicated that SFN induced caspase- 3 activity via cleaved procaspase- 3 and apoptosis after SFN incubation. As shown in Figure 6(c), the SFN elevated caspase-2, -3, -8, -9 activities in five CRC cell lines that have been decreased with caspase-specific inhibitors. The results summarized in Figure 6 indicate that the increased levels of caspase activity may play an important role in SFN-induced apoptosis in CRC cell lines.

3.9. SFN-Induced DNA Fragmentation in CRC Cell Lines. Cells undergoing apoptosis will lose part of their DNA (due to the DNA fragmentation in later apoptosis) [29]. It is hypothesized that SFN could induce apoptosis of CRC cell lines via DNA fragmentation. To explore this effect of SFN against the five CRC cell lines, an in vitro study was initiated by treating each of the cell lines with SFN for 24 hours. The quantification of DNA fragmentation was measured by the fluorescence intensities from flow cytometry (Figure 6(d)), showing that DNA fragmentation levels were significantly increased in cells incubated with SFN. Taken together, the observations imply that SFN has significantly induced the DNA fragmentation of CRC cells.

3.10. SFN Inhibits Tumor Growth in SCID Mice. Macroscopic tumors were observed on day 21, after injection of SFN and PBS control groups of nude mice. After injection of SFN $400 \mu \mathrm{M}$ in the experimental group, tumors developed slowly. After 21 days of injection of SFN, no mice had died in the three groups, and the tumors were resected and measured. Small pale tumor nodules were observed in the tumors, whereas red and hypervascularized large tumors were present in the PBS control and SFN $200 \mu \mathrm{M}$ tumor cells. The average size of tumors in the experimental group $(400 \mu \mathrm{M})$ was $52.99 \%$ (tumor image size) 


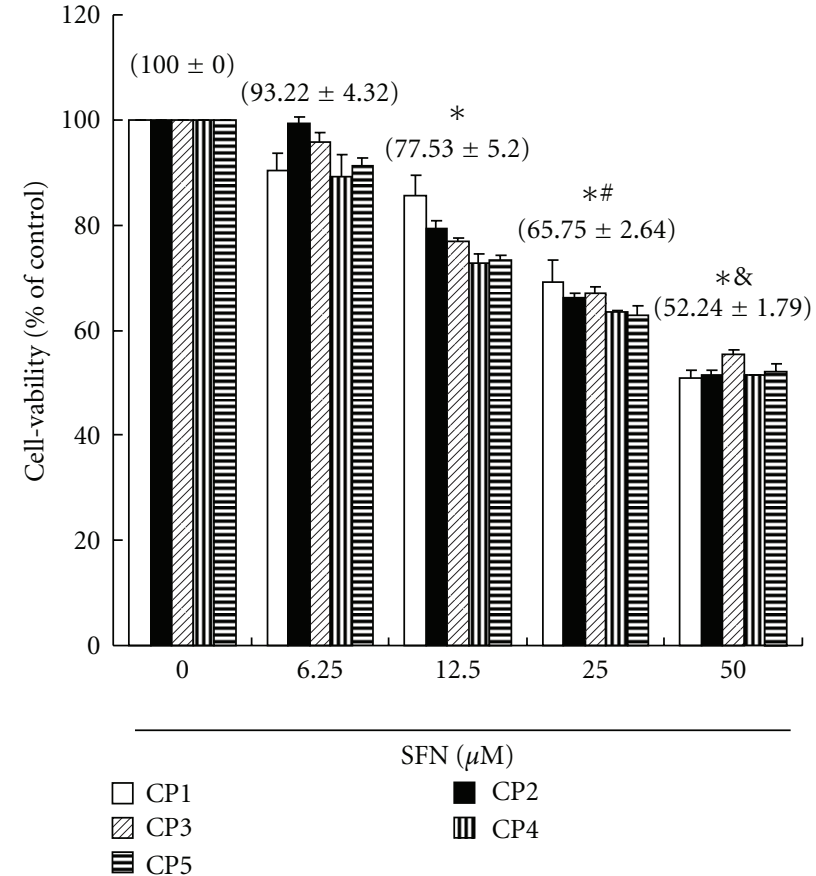

(a)

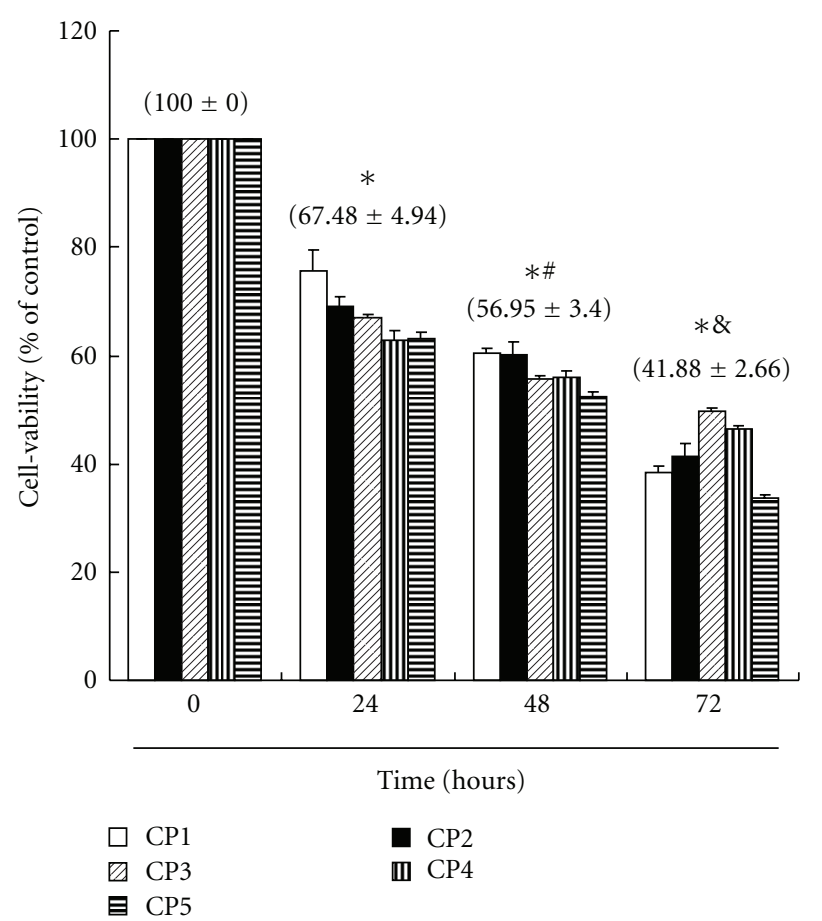

(b)

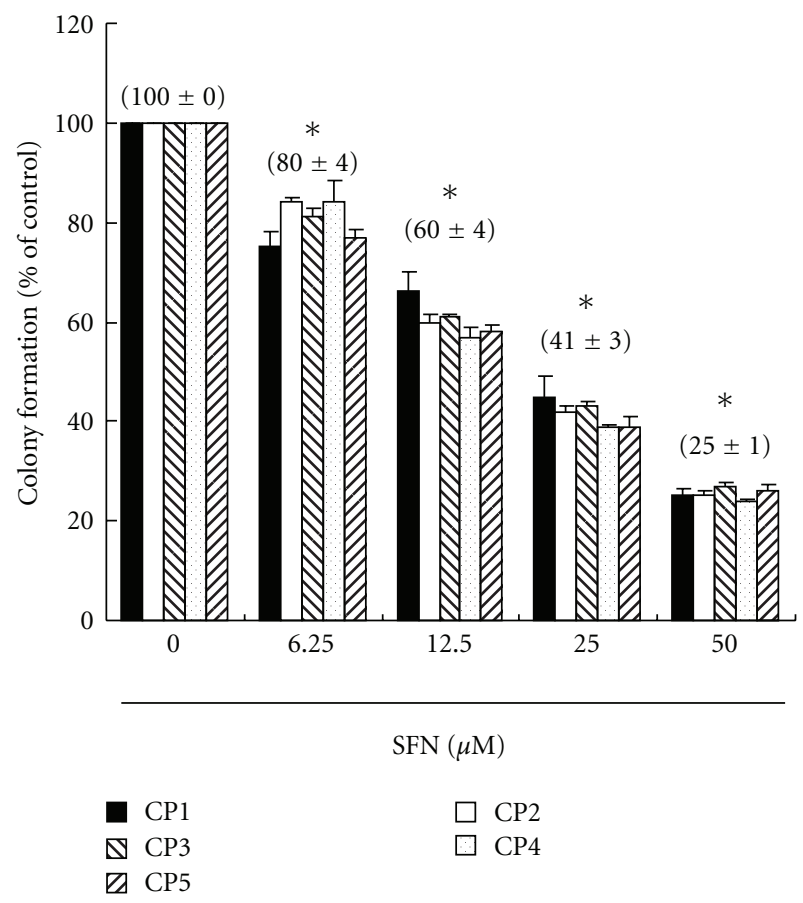

(c)

FIGURE 1: (a) Sulforaphane mediates the survival of five human primary colorectal cancer (CRC) cell lines (five groups, $n=6$ per group) and thus inhibits their proliferation. In vitro study was initiated by treating each of the cell lines to the increasing doses of SFN $(0,6.25,12.5,25$, and $50 \mu \mathrm{M}$ ) for 24 hours. Statistical analysis used the $t$-test, with the significant differences determined at the level of ${ }^{*} P<0.05$ versus control group (SFN $0 \mu \mathrm{M}$ ), while the symbol on the bar denotes the difference which is statistically significant at $P<0.05$ as compared to the 12.5 (\#) or $25 \mu \mathrm{M}$ (\&). (b) Reversibility of the growth inhibitory effect of SFN. The CRC cell lines were each first treated with SFN $12.5 \mu \mathrm{M}$ for 24 hours. After the treatment was terminated by washing off SFN, the cultures were reincubated for 24-72 hours to check the extent of recovery of cancer cells. The survival of these SFN-treated CRC cells was then measured by MTT method. (c) Effect of SFN on colony formation. CRC cells were treated with SFN, and number of colonies was counted. Results were expressed as a percentage of control, which was considered as $100 \%$. All data were reported as the means $( \pm$ SEM) of at least three separate experiments. Statistical analysis used the $t$-test, with the significant differences determined at the level of ${ }^{*} P<0.05$ versus time 0 group, while the symbol on the bar denotes the difference which is statistically significant at $P<0.05$ as compared to the time 24 (\#) or 48 (\&) of the recovery study. 

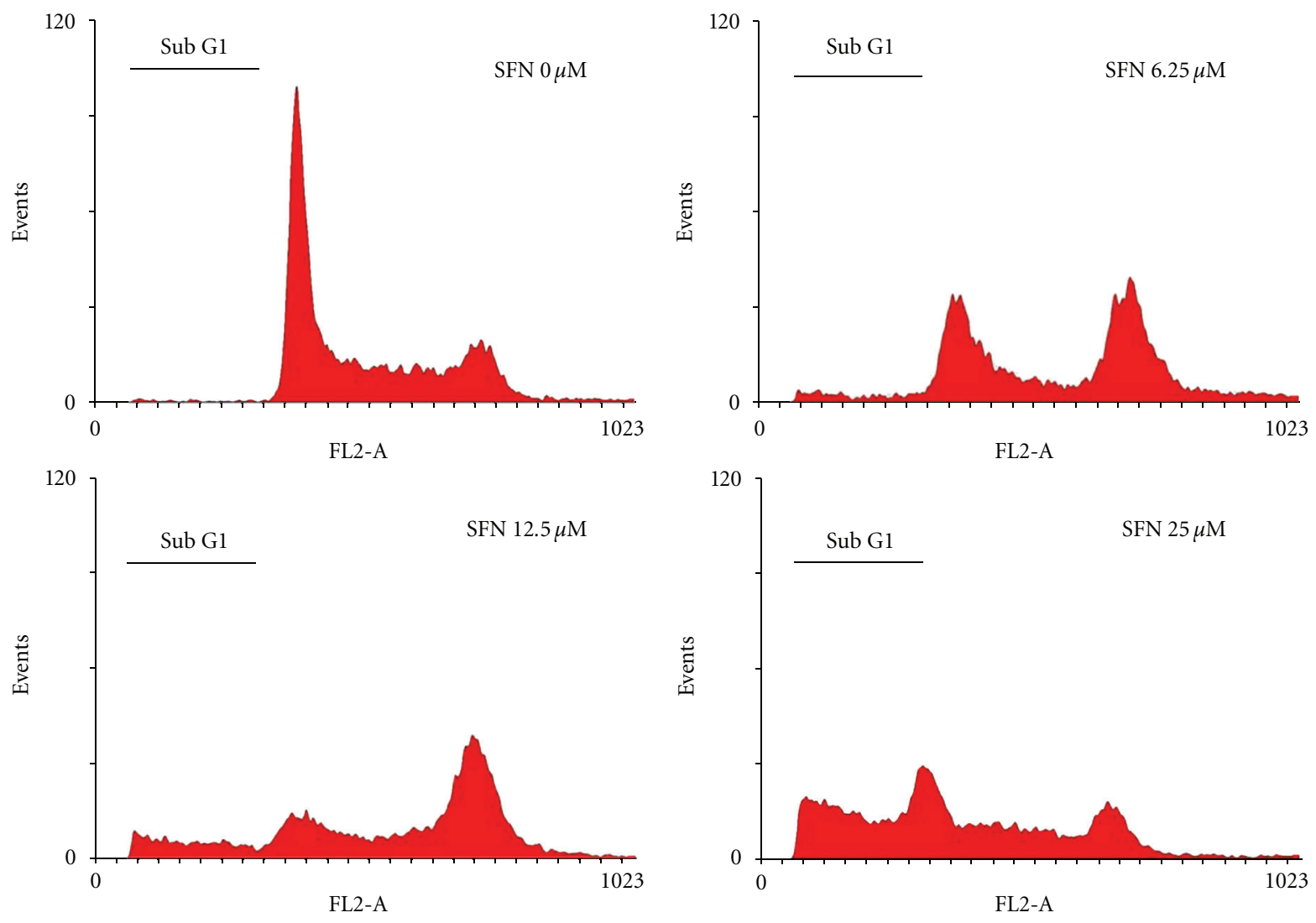

DNA content

(a)

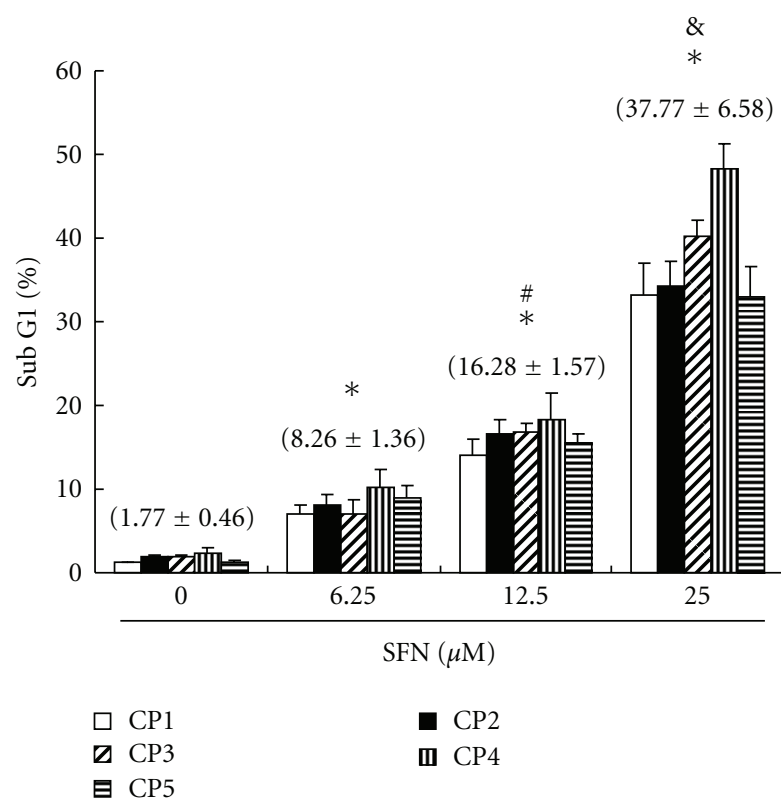

(b)

Figure 2: Arrest of cell cycle progression at G2/M and sub G0/G1 in response to SFN treatment. (a) SFN-induced G2/M (SFN 6.25 $\mu$ M) and G0/G1 (SFN 12.5 and $25 \mu \mathrm{M}$ ) arrest in primary CRC cell lines. The distribution of the cell cycle of CRC cell lines was assessed by flow cytometry after staining with propidium iodide (PI). (b) Results were expressed as a percentage of sub G0/G1. All data were reported as the means $( \pm$ SEM $)$ of at least three separate experiments. Statistical analysis used the $t$-test, with the significant differences determined at the level of ${ }^{*} P<0.05$ versus SFN $0 \mu \mathrm{M}$ group, while the symbol on the bar denotes the difference which is statistically significant at $P<0.05$ as compared to the SFN 6.25 (\#) or $12.5 \mu \mathrm{M}(\&)$. 

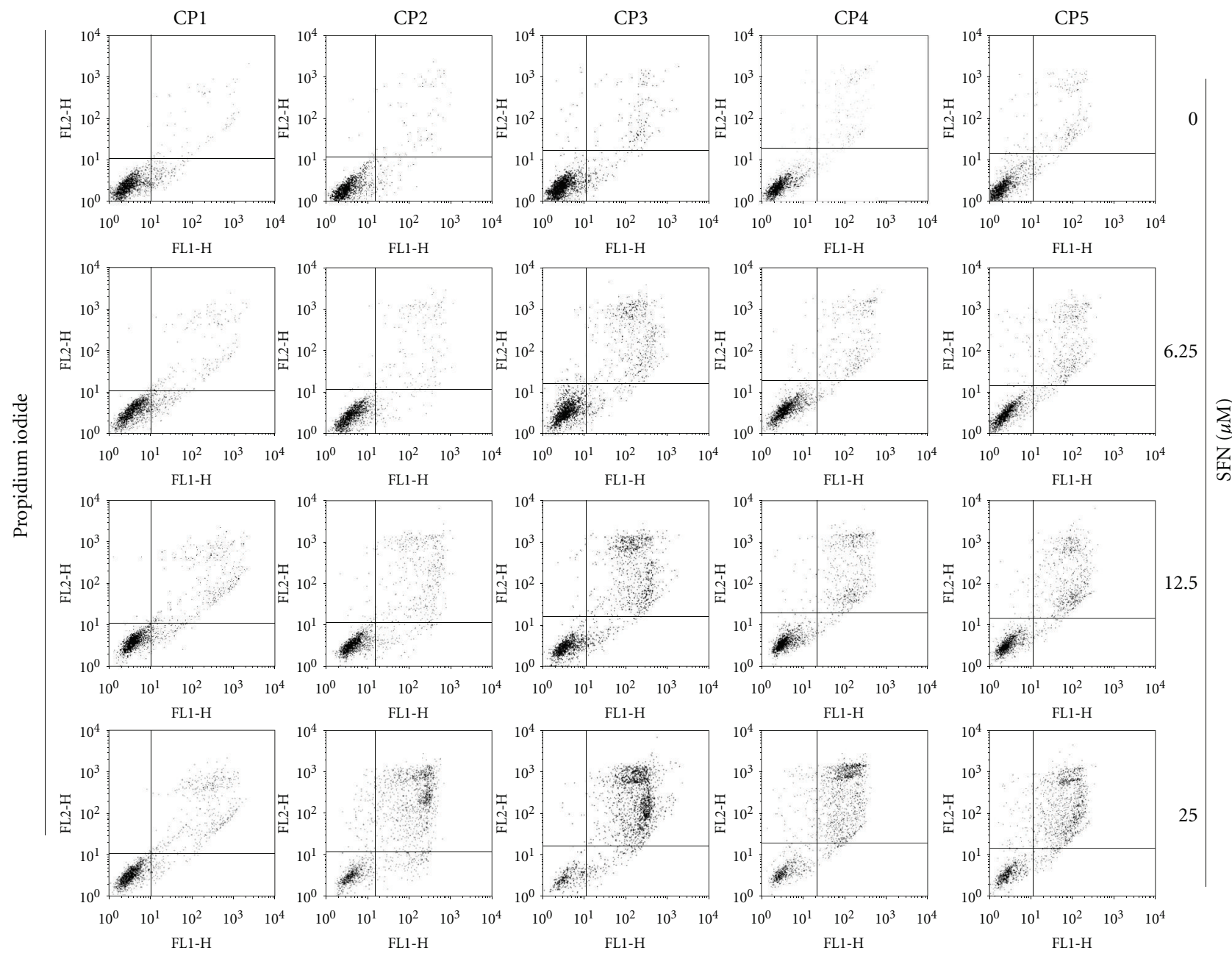

Annexin V

(a)

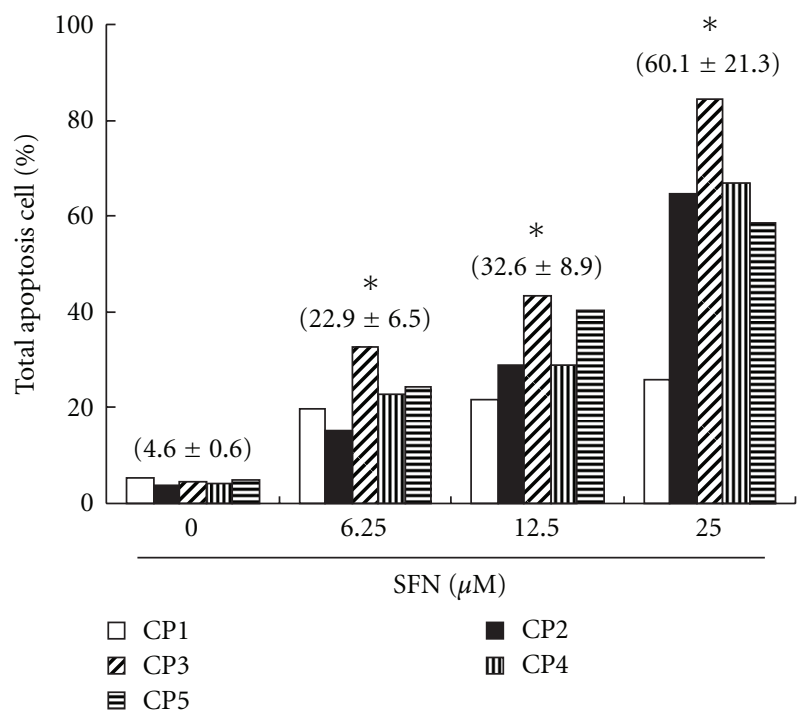

(b)

FigURE 3: Apoptosis of CRC cell lines induced by SFN. Flow cytometric analysis of PI-Annexin-V to quantify SFN-induced apoptosis in CRC cell lines. (a) Dot plots of five CRC cell lines with SFN treatment at $0,6.25,12.5$, and $25 \mu \mathrm{M}$ for $6 \mathrm{~h}$. (b) Results were expressed as a percentage of total apoptosis cells (early and late apoptosis). 

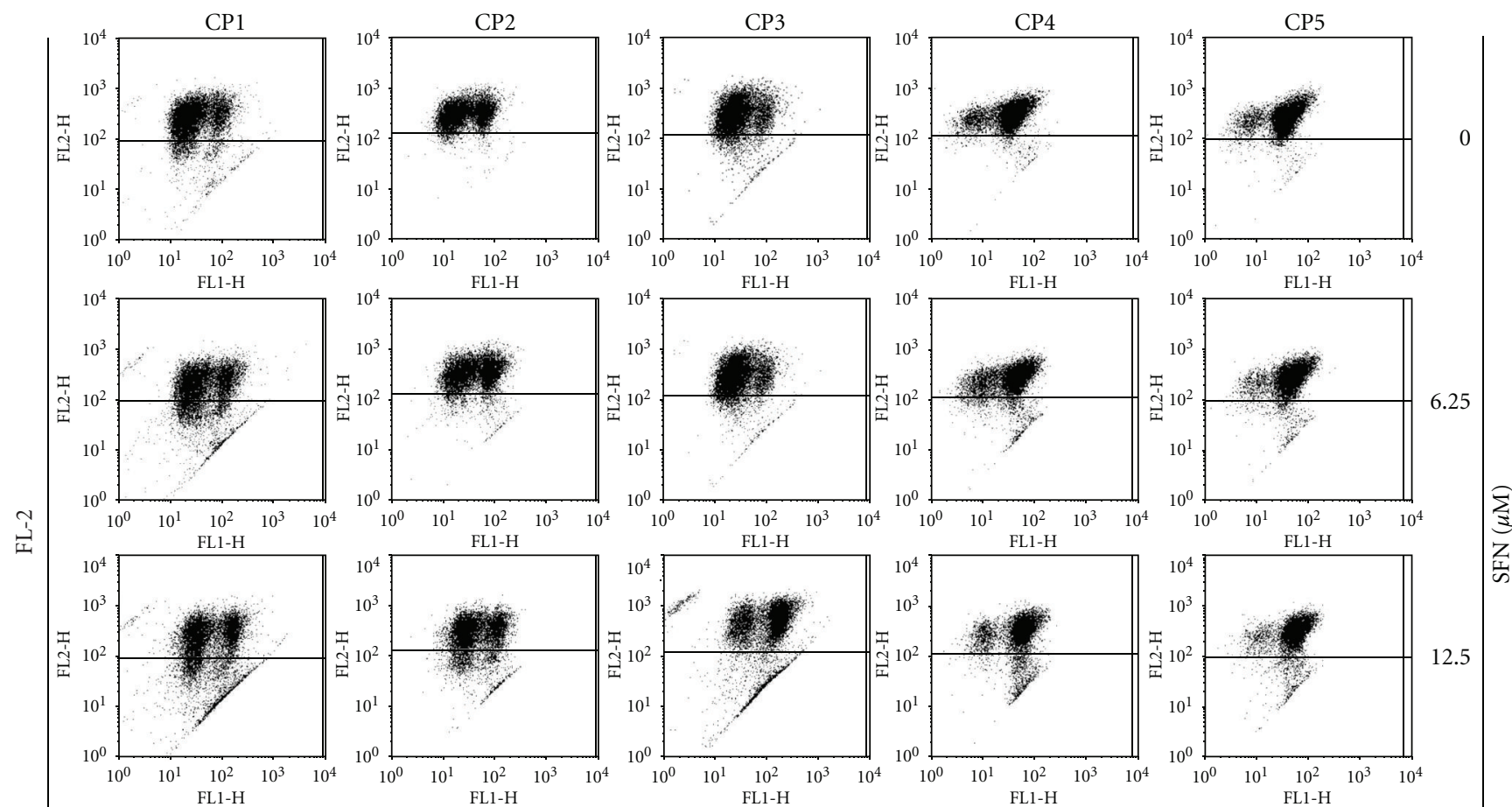

12.5
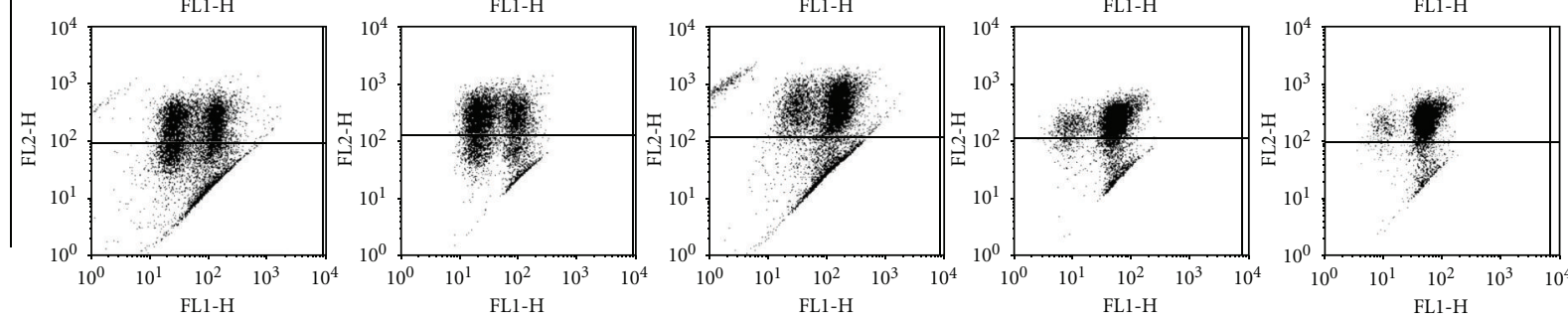

25

FL-1

(a)

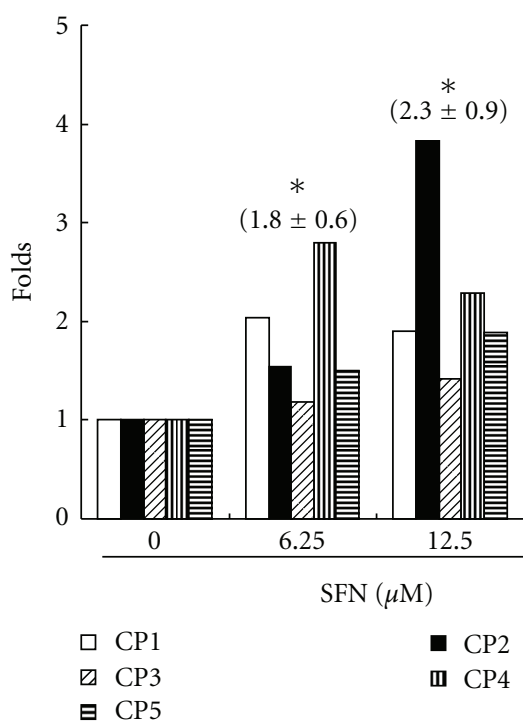

(b)

FIGURE 4: Reduction of the mitochondrial membrane potential $(\Delta \Psi \mathrm{m})$ in the CRC cell lines by SFN, which was determined by JC-1 staining and detected by the flow cytometry. (a) Dot plots of five CRC cell lines with SFN treatment at $0,6.25,12.5$, and $25 \mu \mathrm{M}$ for $6 \mathrm{~h}$. (b) The reduction of the $(\Delta \Psi \mathrm{m})$ containing polarized or depolarized mitochondria determined the ratio of the two fluorescence intensities analyzed by flow cytometry. All the data shown are the folds of five CRC cell lines. The symbol $(*)$ on each group of bars denotes that difference from the treatment with $0 \mu \mathrm{M}$ SFN is statistically significant at $P<0.05$. 


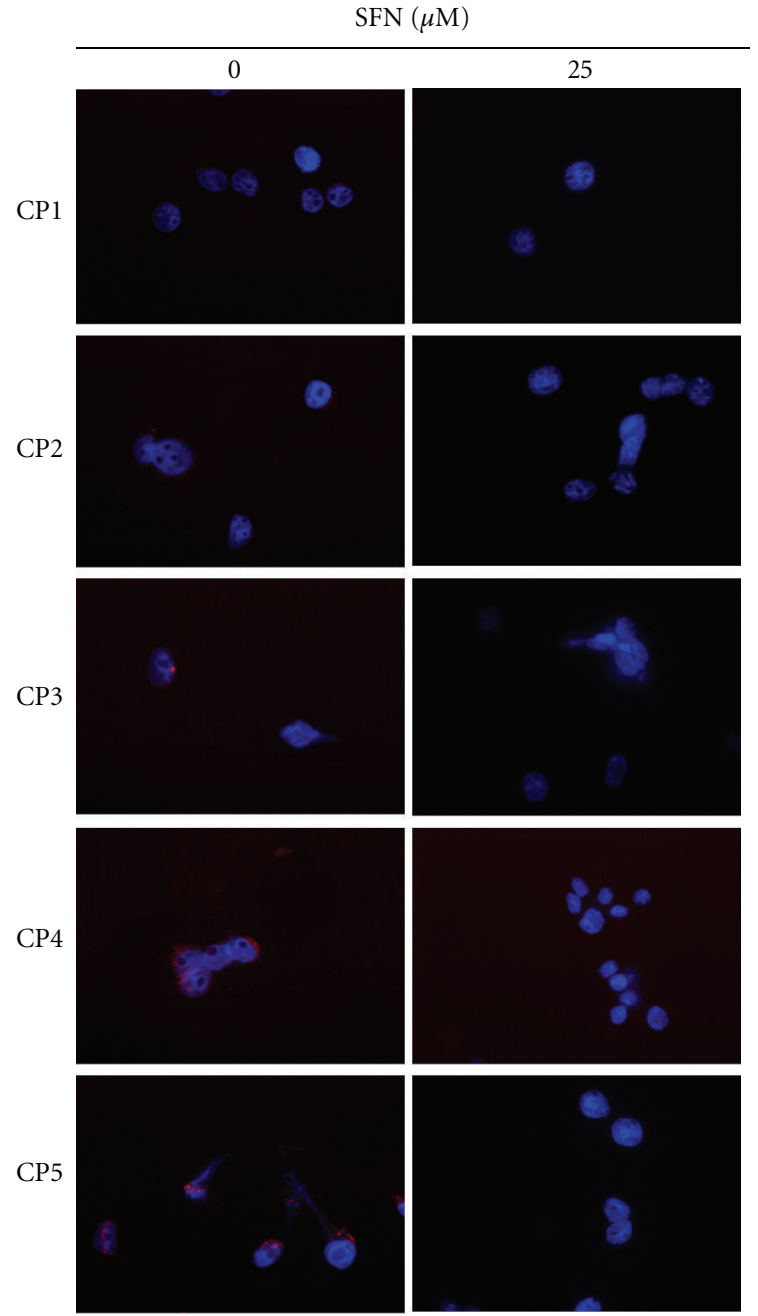

Figure 5: Diminished NF- $\kappa$ B activity in SFN-treated CRC cell lines. Five CRC cell lines were examined for their NF- $\kappa$ B activity 16 hours after SFN stimulation by confocal microscopy of NF- $\kappa$ B subunit p50/52 localization. The CRC cell lines were stained for $\mathrm{p} 50 / 52$ (red). DAPI (blue) indicates nucleus, where active form of NF- $\kappa \mathrm{B}$ subunit $\mathrm{p} 50 / 52$ is found.

and $28.70 \%$ (tumor weight), much less than the average size of the PBS control (100\%) (Figure $7(\mathrm{~b}))$. The results indicated that SFN could decrease tumorigenesis by inhibiting neovascularization in tumors in vivo. SFN might also have inhibitory actions on surrounding tumor tissues and indirectly inhibit tumorigenesis (Figure 7(a)).

\section{Discussion}

Sulforaphane (SFN), a naturally occurring alkyl isothiocyanate, has been shown to be a more potent cytotoxic agent than other synthetic analogues isothiocyanates (ITCs) in cancer cells [30]. In a previous study, sulforaphane-treated cells showed growth arrest and cell cycle G2/M accumulation [31]. However, this effect seemed to be independent of a DNA damage Chk1-cdc2-mediated pathway, unlike the $\mathrm{G}_{2}$ arrest mediated by radiation, and seemed to be predominantly a metaphase arrest [32]. The effects of SFN may occur by the disruption of microtubules, whereupon it is expected that the activity of the mitotic spindle checkpoint is maintained and arrests cells in metaphase [33]. Of interest, our findings suggest that cell cycle G2/M arrests at the low SFN doses $(6.25 \mu \mathrm{M})$, whereas apoptosis and caspase activation dominate at the higher doses $(12.5$ and $25 \mu \mathrm{M})$ in five CRC cell lines. The results of mechanical analysis have led us to conclude that both the inhibition of proliferation and the induction of apoptosis are highly dependent upon the SFN. However, on further investigation, our data suggest a more complex mechanism involving cell cycle deregulation and apoptosis that seems to reflect differences in degree of SFN-induced toxicity between the CRC cell lines.

The most common cell death mode on SFN treatment seems to be apoptosis [22]. Two major apoptotic pathways exist: the death receptor and the mitochondrial pathways [34]. Multiple apoptotic stimuli trigger the activation of proteases called caspases, which in turn initiate and execute the apoptotic program [35]. One of the hallmarks of the terminal stages of apoptosis is internucleosomal DNA breakdown, which was first recognized in [36]. Recent studies have led to the discovery of two major apoptotic nucleases, termed DNA fragmentation factor (DFF) [37] or caspaseactivated DNase (CAD) [38], and endonuclease G. Both endonucleases attack chromatin to yield 3-hydroxyl and 5phosphate termini, first creating 50 - to $300-\mathrm{kb}$ cleavage products and then oligonucleosomal fragmentation, but these nucleases show different cellular locations and are regulated in fundamentally different ways. Although activation of the executorial caspases seems to be indispensable for realization of the apoptotic program, several forms of cell demise have been shown to be caspase independent or even accelerated by caspase inhibitors [39]. In a previous study, the SFN activated the caspase-8-dependent death receptor pathway, coinciding with the activation of the mitochondrial pathway [40]. Activation of caspase- 8 can cleave the $\mathrm{BH} 3$ family member Bid [41]. Truncated Bid then migrates to the mitochondria, leading to the loss of MMP, cytochrome $c$ release, and activation of the initiator caspase-9 [42]. The observations of this study have implied that SFN has significantly induced the caspase-3 activity of CRC cell lines. Caspase-3-like activity and plasma membrane disintegration served as measures of early apoptosis whereas nuclear fragmentation served as indicator of late apoptosis events [29].

Nuclear factor $\kappa \mathrm{B}(\mathrm{NF}-\kappa \mathrm{B})$ plays an important role in inflammation, autoimmune response, cell proliferation, and apoptosis by regulating the expression of genes involved in these processes [43]. Active NF- $\kappa \mathrm{B}$ is most commonly composed of the heterodimer DNA-binding subunits p50 and $\mathrm{p} 65$. It has recently been shown that inactivation of $\mathrm{p} 65$ subunit of NF- $\kappa \mathrm{B}$ leads to the death through apoptosis of liver cells [44]. Similarly, it has been shown in a wide range of cells that when NF- $\kappa \mathrm{B}$ has been inactivated by $\mathrm{I} \kappa-\mathrm{B} \alpha$, cells were more sensitive to TNF- $\alpha$-induced apoptosis. Evidence exists for NF- $\kappa \mathrm{B}$ playing both anti- and proapoptosis roles [45]. The reducing levels of NF- $\kappa \mathrm{B}$ may be involved in SFNinduced apoptosis of CRC cells. 


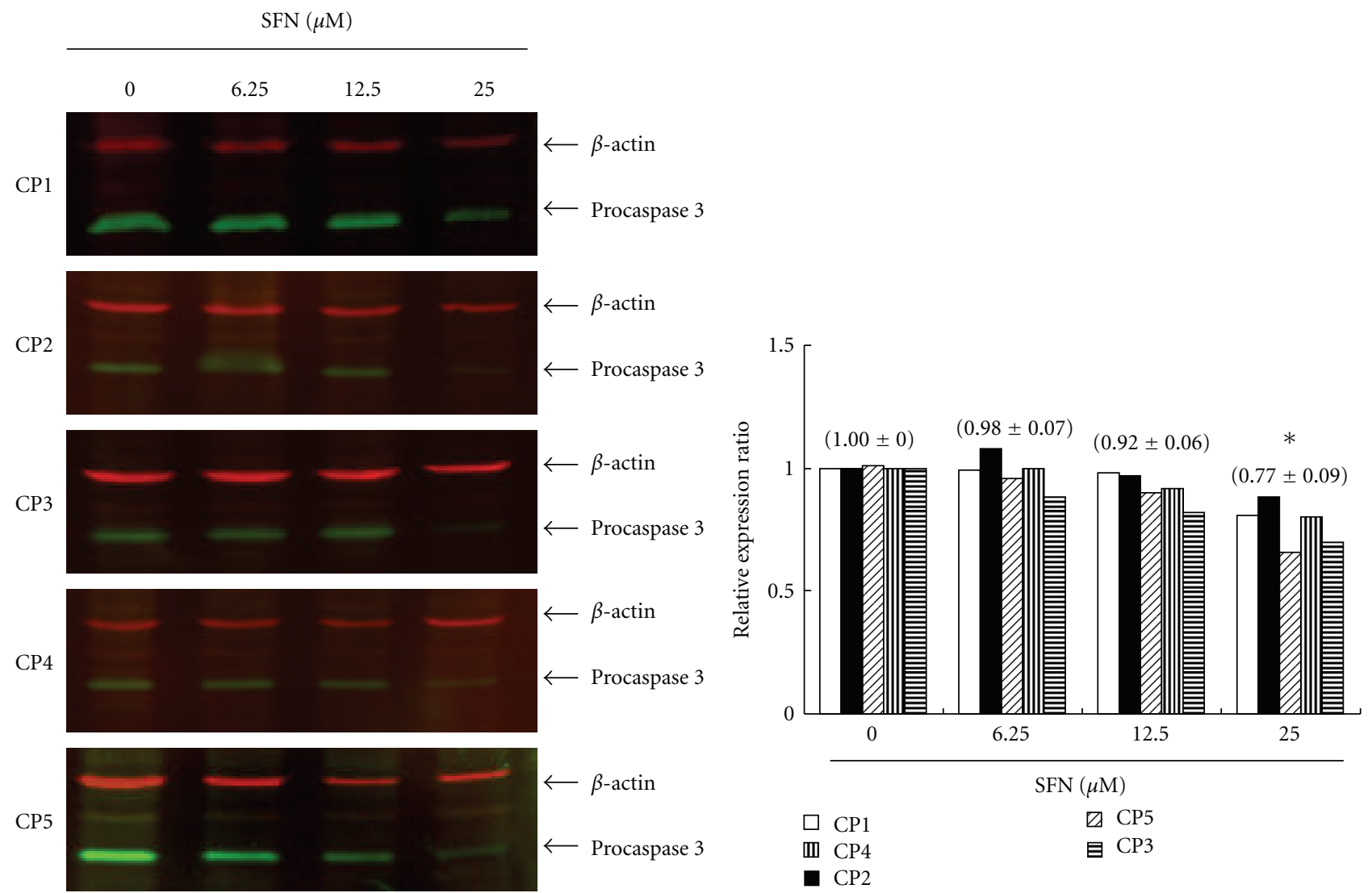

(a)

(b)

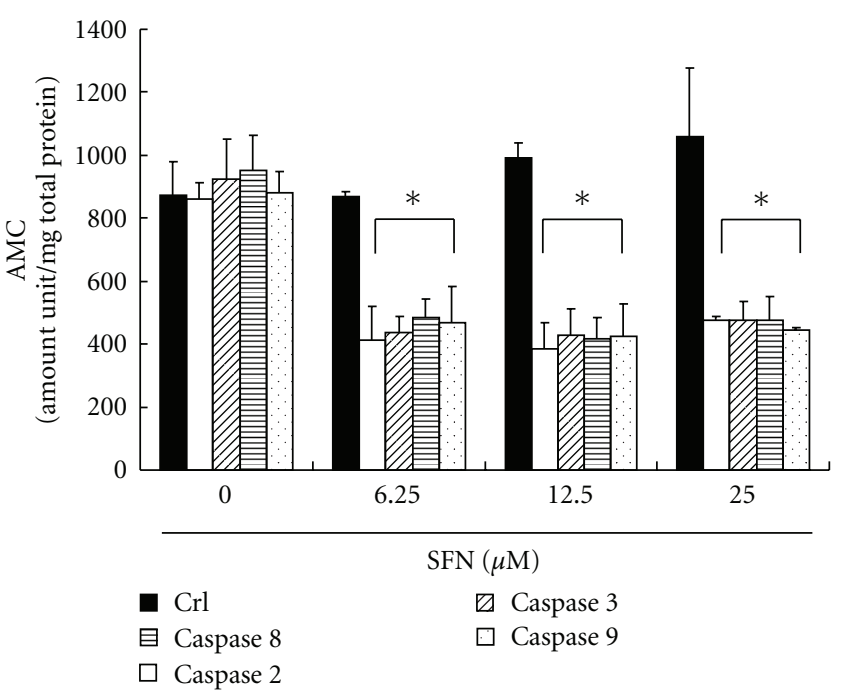

(c)

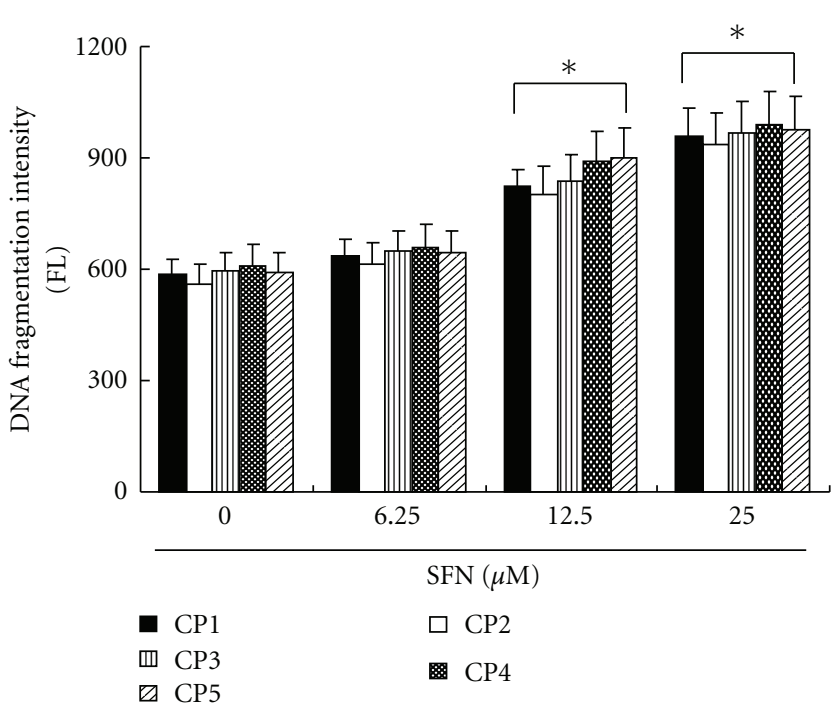

(d)

FIGURE 6: SFN activates procaspase-3 degradation in five CRC cell lines. The cells were treated with SFN $(0,6.25,12.5$, and $25 \mu \mathrm{M})$ for 24 hours, and then Western blot analysis was performed for procaspase-3. (a) Representative blot from 3 independent experiments. (b) Quantification of band intensities by Li-COR near infrared imaging system. (c) The caspase-2, $-3,-8,-9$ activity was analyzed by ApoAlert Caspase assay plates. SFN induces the caspase activity of five CRC cell lines. (d) Quantification of DNA fragmentation by measuring the fluorescence intensities by flow cytometry. The data showed that DNA fragmentation levels were significantly elevated in cells incubated with SFN incubation for 24 hours. All data were reported as the means $( \pm$ SEM) of five CRC cell lines. Statistical analysis used the $t$-test, with the significant differences determined at the level of $* P<0.05$ versus $0 \mu \mathrm{M}$ control group. 

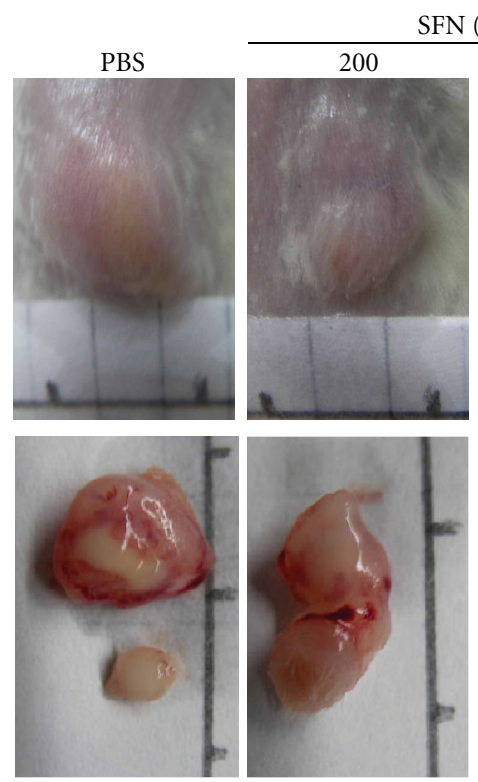

(a)

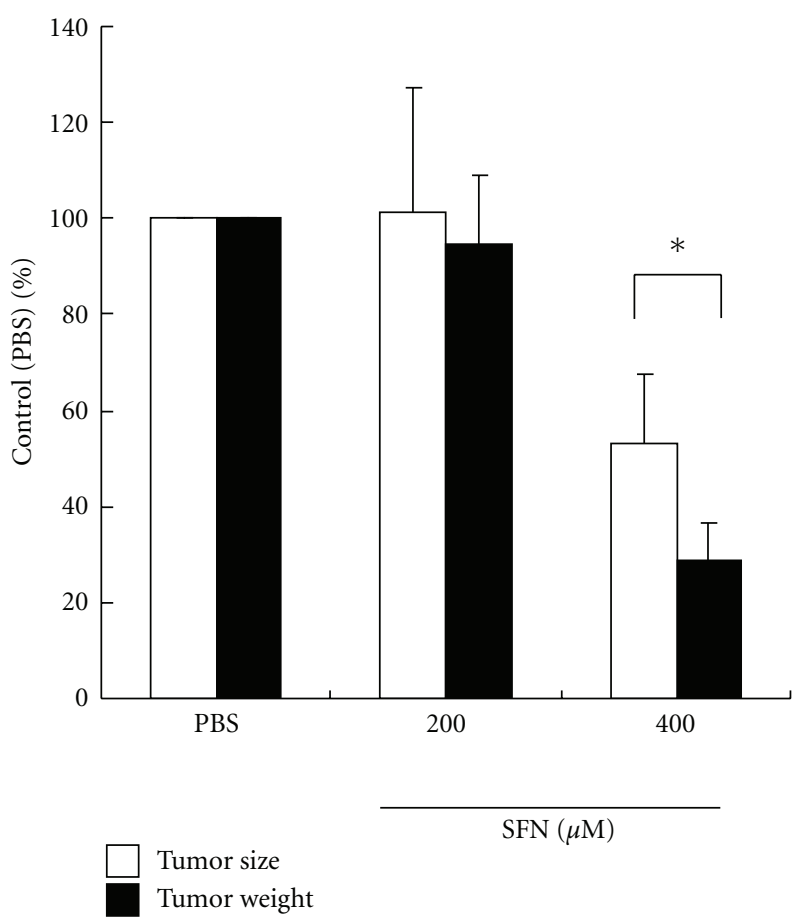

(b)

FIGURE 7: SFN inhibits in vivo tumor growth. (a) Effects of SFN on tumor growth of SCID mice subcutaneously inoculated with primary human CRC cell lines. The results showed that SFN $400 \mu \mathrm{M}$ inhibited tumor growth significantly in both cancer xenografts. (b) Inhibition of tumor growth was compared among tested groups. The inhibitory ratio was normalized to the negative control (PBS group) (values represent percent of control, $n=3{ }^{*} P<0.05$ versus PBS group).

Recent studies have shown that SFN inhibited growth of tumor precursors [46] and growth of tumors in mice models when treatment was started at the time of carcinogen administration [47]. The inhibition of PI3K/AKT and ERK pathways acts together to activate FOXO transcription factor and enhances SFN-induced FOXO transcriptional activity, leading to cell cycle arrest and apoptosis [48]. We now show that growth of established s.c. CRC tumor xenografts was suppressed by SFN treatment. Sulforaphane and related isothiocyanate compounds should therefore be investigated further as antitumor agents in addition to their established effects in cancer prevention.

In conclusion, we have demonstrated that SFN inhibits tumor growth by inducing caspase and mitochondrial pathway apoptosis and by arresting the cell cycle at G2/M phase. Our results show that SFN might be an effective anticancer drug for cancer therapy and provide preliminary basis for its clinical application. However, further work is still needed to separate its bioactive components for further drug development.

\section{Conflict of Interests}

The authors have declared no conflict of interests.

\section{Acknowledgment}

The authors acknowledge the financial support from the Chang Jung Christian University grant Q99003.

\section{References}

[1] S. Mukherjee, R. K. Bhattacharya, and M. Roy, "Targeting protein kinase $\mathrm{C}(\mathrm{PKC})$ and telomerase by phenethyl isothiocyanate (PEITC) sensitizes PC-3 cells towards chemotherapeutic drug-induced apoptosis," Journal of Environmental Pathology, Toxicology and Oncology, vol. 28, no. 4, pp. 269-282, 2009.

[2] P. Šmerák, Z. Polívková, R. Štětina, J. Bártová, and I. Bárta, "Antimutagenic effect of phenethyl isothiocyanate," Central European Journal of Public Health, vol. 17, no. 2, pp. 86-92, 2009.

[3] S. D. Stan, S. V. Singh, and R. E. Brand, "Chemoprevention strategies for pancreatic cancer," Nature Reviews Gastroenterology and Hepatology, vol. 7, no. 6, pp. 347-356, 2010.

[4] T. Matsuda, T. Maruyama, H. Iizuka et al., "Phthalate esters reveal skin-sensitizing activity of phenethyl isothiocyanate in mice," Food and Chemical Toxicology, vol. 48, no. 6, pp. 17041708, 2010.

[5] T.-T. Liu and T.-S. Yang, "Stability and antimicrobial activity of allyl isothiocyanate during long-term storage in an oil-inwater emulsion," Journal of Food Science, vol. 75, no. 5, pp. C445-C451, 2010.

[6] S. S. Beevi, L. N. Mangamoori, V. Dhand, and D. S. Ramakrishna, "Isothiocyanate profile and selective antibacterial activity of root, stem, and leaf extracts derived from Raphanus sativus L," Foodborne Pathogens and Disease, vol. 6, no. 1, pp. 129-136, 2009.

[7] I. Herr and M. W. Büchler, "Dietary constituents of broccoli and other cruciferous vegetables: implications for prevention 
and therapy of cancer," Cancer Treatment Reviews, vol. 36, no. 5, pp. 377-383, 2010.

[8] P. Riso, D. Martini, P. Møller et al., "DNA damage and repair activity after broccoli intake in young healthy smokers," Mutagenesis, vol. 25, no. 6, pp. 595-602, 2010.

[9] K. K. Brown, F. H. Blaikie, R. A. J. Smith et al., "Direct modification of the proinflammatory cytokine macrophage migration inhibitory factor by dietary isothiocyanates," Journal of Biological Chemistry, vol. 284, no. 47, pp. 32425-32433, 2009.

[10] M. D. Yang, K. C. Lai, T.Y. Lai, S. C. Hsu, C. L. Kuo, C. S. Yu et al., "Phenethyl isothiocyanate inhibits migration and invasion of human gastric cancer AGS cells through suppressing MAPK and NF- $\kappa$ B signal pathways," Anticancer Research, vol. 30, no. 6, pp. 2135-2143, 2010.

[11] A. Bhattacharya, L. Tang, Y. Li et al., "Inhibition of bladder cancer development by allyl isothiocyanate," Carcinogenesis, vol. 31, no. 2, pp. 281-286, 2009.

[12] T. Maeda, Y. Miyazono, K. Ito, K. Hamada, S. Sekine, and T. Horie, "Oxidative stress and enhanced paracellular permeability in the small intestine of methotrexate-treated rats," Cancer Chemotherapy and Pharmacology, vol. 65, no. 6, pp. 1117-1123, 2010.

[13] N. Miyoshi, E. Watanabe, T. Osawa et al., "ATP depletion alters the mode of cell death induced by benzyl isothiocyanate," Biochimica et Biophysica Acta, vol. 1782, no. 10, pp. 566-573, 2008.

[14] K. Hasegawa, S. Miwa, K. Tsutsumiuchi, and J. Miwa, "Allyl isothiocyanate that induces GST and UGT expression confers oxidative stress resistance on C. elegans, as demonstrated by nematode biosensor," PLoS ONE, vol. 5, no. 2, article e9267, 2010.

[15] P. K. Mishra, H. Panwar, A. Bhargava et al., "Isocyanates induces DNA damage, apoptosis, oxidative stress, and inflammation in cultured human lymphocytes," Journal of Biochemical and Molecular Toxicology, vol. 22, no. 6, pp. 429-440, 2008.

[16] S. Adsule, S. Banerjee, F. Ahmed, S. Padhye, and F. H. Sarkar, "Hybrid anticancer agents: isothiocyanate-progesterone conjugates as chemotherapeutic agents and insights into their cytotoxicities," Bioorganic and Medicinal Chemistry Letters, vol. 20, no. 3, pp. 1247-1251, 2010.

[17] J. V. Higdon, B. Delage, D. E. Williams, and R. H. Dashwood, "Cruciferous vegetables and human cancer risk: epidemiologic evidence and mechanistic basis," Pharmacological Research, vol. 55, no. 3, pp. 224-236, 2007.

[18] M. Li, Q. Wang, W. Lin, and B. Wang, "Regulation of ovarian cancer cell adhesion and invasion by chloride channels," International Journal of Gynecological Cancer, vol. 19, no. 4, pp. 526-530, 2009.

[19] F. D’Agostini, L. Mastracci, A. Izzotti et al., "Modulation by phenethyl isothiocyanate and budesonide of molecular and histopathologic alterations induced by environmental cigarette smoke in mice," Cancer Prevention Research, vol. 2, no. 6, pp. 546-556, 2009.

[20] M. G. Kim and H. S. Lee, "Growth-inhibiting activities of phenethyl isothiocyanate and its derivatives against intestinal bacteria," Journal of Food Science, vol. 74, no. 8, pp. M467M471, 2009.

[21] S. Hayashi, E. Nakamura, Y. Kubo et al., "Impairment by allyl isothiocyanate of gastric epithelial wound repair through inhibition of ion transporters," Journal of Physiology and Pharmacology, vol. 59, no. 4, pp. 691-706, 2008.

[22] M. H. Traka, C. A. Spinks, J. F. Doleman et al., "The dietary isothiocyanate sulforaphane modulates gene expression and alternative gene splicing in a PTEN null preclinical murine model of prostate cancer," Molecular Cancer, vol. 13, p. 189, 2010.

[23] Y. Shan, K. Wu, W. Wang et al., "Sulforaphane downregulates COX-2 expression by activating p38 and inhibiting NF- $\kappa$ B-DNA-binding activity in human bladder T24 cells," International Journal of Oncology, vol. 34, no. 4, pp. 11291134, 2009.

[24] S. Choi, K. L. Lew, H. Xiao et al., "D,L-Sulforaphane-induced cell death in human prostate cancer cells is regulated by inhibitor of apoptosis family proteins and Apaf-1," Carcinogenesis, vol. 28, no. 1, pp. 151-162, 2007.

[25] L. Mao, H. D. Wang, X. L. Wang, L. Qiao, and H. X. Yin, "Sulforaphane attenuates matrix metalloproteinase-9 expression following spinal cord injury in mice," Annals of Clinical and Laboratory Science, vol. 40, no. 4, pp. 354-360, 2010.

[26] M. Zhu, Y. Zhang, S. Cooper, E. Sikorski, J. Rohwer, and G. T. Bowden, "Phase II enzyme inducer, sulforaphane, inhibits UVB-induced AP-1 activation in human keratinocytes by a novel mechanism," Molecular Carcinogenesis, vol. 41, no. 3, pp. 179-186, 2004.

[27] Y. C. Hsu, H. C. Weng, S. Lin, and Y. W. Chien, "Curcuminoids-cellular uptake by human primary colon cancer cells as quantitated by a sensitive HPLC assay and its relation with the inhibition of proliferation and apoptosis," Journal of Agricultural and Food Chemistry, vol. 55, no. 20, pp. 8213-8222, 2007.

[28] L. C. Yen, Y. S. Yeh, C. W. Chen et al., "Detection of KRAS oncogene in peripheral blood as a predictor of the response to cetuximab plus chemotherapy in patients with metastatic colorectal cancer," Clinical Cancer Research, vol. 15, no. 13, pp. 4508-4513, 2009.

[29] U. Wenzel and H. Daniel, "Early and late apoptosis events in human transformed and non-transformed colonocytes are independent on intracellular acidification," Cellular Physiology and Biochemistry, vol. 14, no. 1-2, pp. 65-76, 2004.

[30] N. P. Gullett, A. R. M. R. Amin, S. Bayraktar et al., "Cancer prevention with natural compounds," Seminars in Oncology, vol. 37, no. 3, pp. 258-281, 2010.

[31] T. A. Matsui, H. Murata, T. Sakabe et al., "Sulforaphane induces cell cycle arrest and apoptosis in murine osteosarcoma cells in vitro and inhibits tumor growth in vivo," Oncology Reports, vol. 18, no. 5, pp. 1263-1268, 2007.

[32] S. V. Singh, A. Herman-Antosiewicz, A. V. Singh et al., "Sulforaphane-induced G2/M phase cell cycle arrest involves checkpoint kinase 2-mediated phosphorylation of cell division cycle 25C," Journal of Biological Chemistry, vol. 279, no. 24, pp. 25813-25822, 2004.

[33] S. J. Jackson and K. W. Singletarym, "Sulforaphane: a naturally occurring mammary carcinoma mitotic inhibitor, which disrupts tubulin polymerization," Carcinogenesis, vol. 25, no. 2, pp. 219-227, 2004.

[34] A. S. Keck, R. Staack, and E. H. Jeffery, “The cruciferous nitrile crambene has bioactivity similar to sulforaphane when administered to Fischer 344 rats but is far less potent in cell culture," Nutrition and Cancer, vol. 42, no. 2, pp. 233-240, 2002.

[35] M. P. Mattson, "Dietary factors, hormesis and health," Ageing Research Reviews, vol. 7, no. 1, pp. 43-48, 2008

[36] C. T. Yeh and G. C. Yen, "Effect of sulforaphane on metallothionein expression and induction of apoptosis in human hepatoma HepG2 cells," Carcinogenesis, vol. 26, no. 12, pp. 2138-2148, 2005. 
[37] A.-C. Cheng, M.-F. Lee, M.-L. Tsai et al., "Rosmanol potently induces apoptosis through both the mitochondrial apoptotic pathway and death receptor pathway in human colon adenocarcinoma COLO 205 cells," Food and Chemical Toxicology, vol. 49, no. 2, pp. 485-493, 2010.

[38] B. D. Larsen and L. A. Megeney, "Parole terms for a killer: directing caspase3/CAD induced DNA strand breaks to coordinate changes in gene expression," Cell Cycle, vol. 9, no. 15, pp. 2940-2945, 2010.

[39] J. J. Monsuez, J. C. Charniot, N. Vignat, and J. Y. Artigou, "Cardiac side-effects of cancer chemotherapy," International Journal of Cardiology, vol. 144, no. 1, pp. 3-15, 2010.

[40] C. Fimognari, M. Nüsse, M. Lenzi, D. Sciuscio, G. CantelliForti, and P. Hrelia, "Sulforaphane increases the efficacy of doxorubicin in mouse fibroblasts characterized by $\mathrm{p} 53$ mutations," Mutation Research, vol. 601, no. 1-2, pp. 92-101, 2006.

[41] Z. T. Schug, F. Gonzalvez, R. H. Houtkooper, F. M. Vaz, and E. Gottlieb, "BID is cleaved by caspase- 8 within a native complex on the mitochondrial membrane," Cell Death and Differentiation, vol. 18, no. 3, pp. 538-548, 2010.

[42] S. Shankar, S. Ganapathy, and R. K. Srivastava, "Sulforaphane enhances the therapeutic potential of TRAIL in prostate cancer orthotopic model through regulation of apoptosis, metastasis, and angiogenesis," Clinical Cancer Research, vol. 14, no. 21, pp. 6855-6866, 2008.

[43] S. Luqman and J. M. Pezzuto, "NF- $\kappa$ B: a promising target for natural products in cancer chemoprevention," Phytotherapy Research, vol. 24, no. 7, pp. 949-963, 2010.

[44] S. M. Robinson and D. A. Mann, "Role of nuclear factor kappaB in liver health and disease," Clinical Science, vol. 118, no. 12, pp. 691-705, 2010.

[45] W. Chen, X. Wang, L. Bai, X. Liang, J. Zhuang, and Y. Lin, "Blockage of NF- $\kappa$ B by IKK $\beta$ - or RelA-siRNA rather than the NF- $\kappa \mathrm{B}$ super-suppressor $\mathrm{I} \kappa \mathrm{B} \alpha$ mutant potentiates Adriamycin-induced cytotoxicity in lung cancer cells," Journal of Cellular Biochemistry, vol. 105, no. 2, pp. 554-561, 2008.

[46] D. Brunelli, M. Tavecchio, C. Falcioni et al., "The isothiocyanate produced from glucomoringin inhibits NF-kB and reduces myeloma growth in nude mice in vivo," Biochemical Pharmacology, vol. 79, no. 8, pp. 1141-1148, 2010.

[47] C. Fimognari and P. Hrelia, "Sulforaphane as a promising molecule for fighting cancer," Mutation Research, vol. 635, no. 2-3, pp. 90-104, 2007.

[48] S. K. Roy, R. K. Srivastava, and S. Shankar, "Inhibition of PI3K/AKT and MAPK/ERK pathways causes activation of FOXO transcription factor, leading to cell cycle arrest and apoptosis in pancreatic cancer," Journal of Molecular Signaling, vol. 5, p. 10, 2010. 


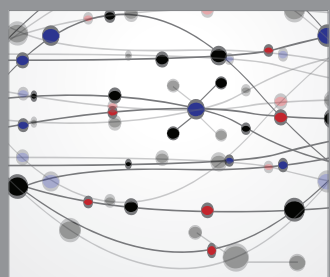

The Scientific World Journal
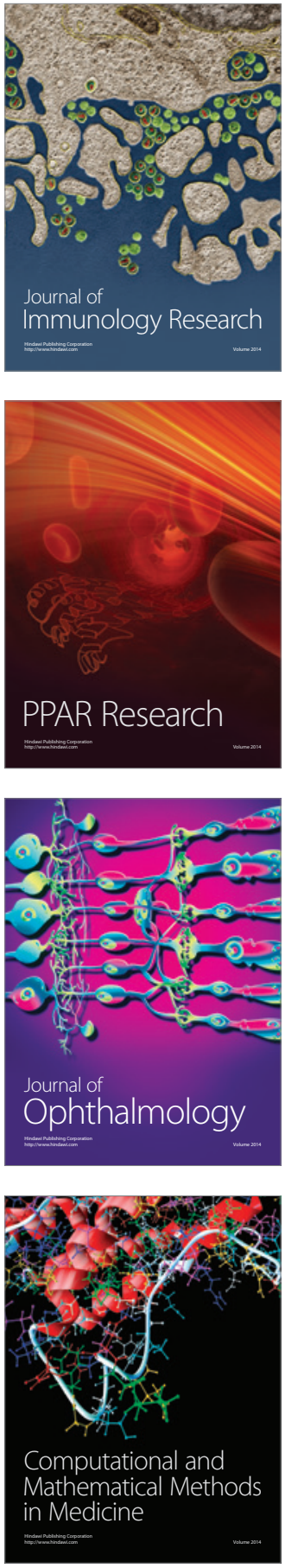

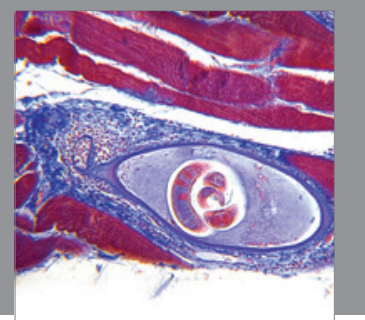

Gastroenterology

Research and Practice
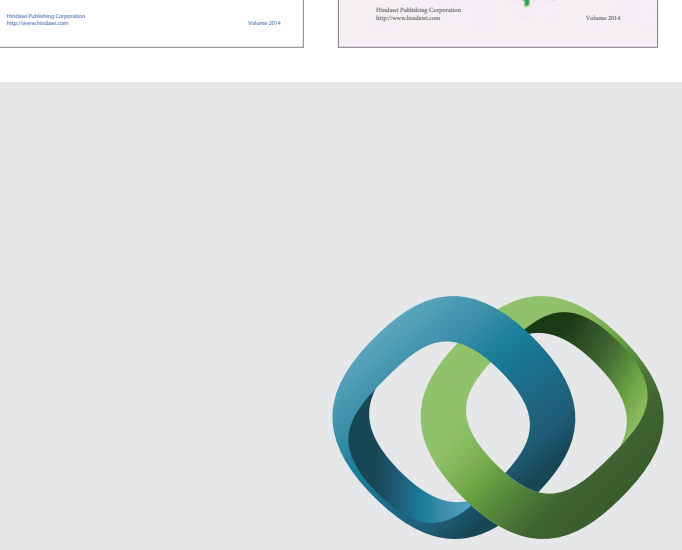

\section{Hindawi}

Submit your manuscripts at

http://www.hindawi.com
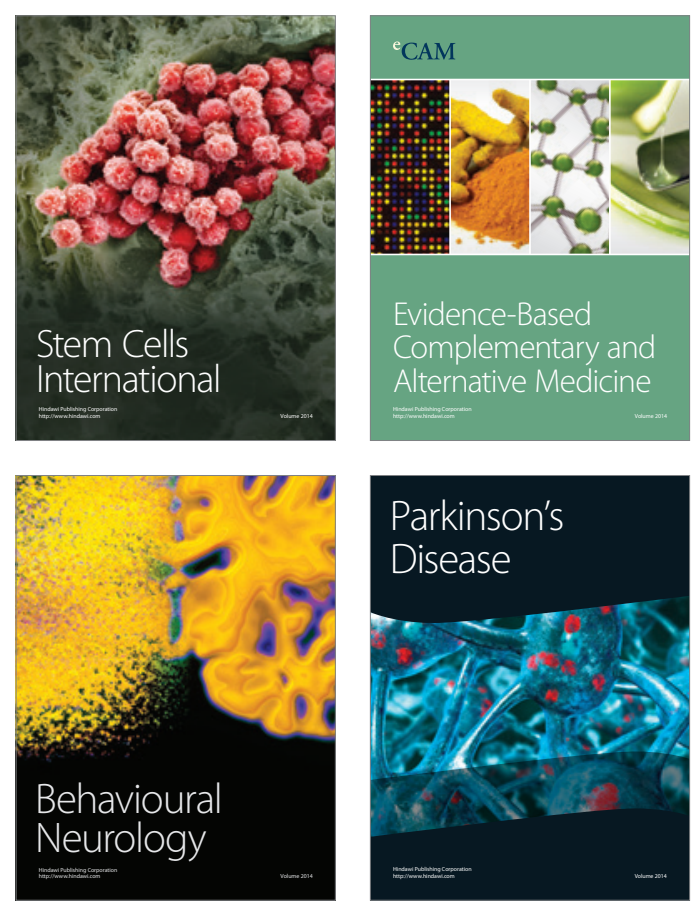

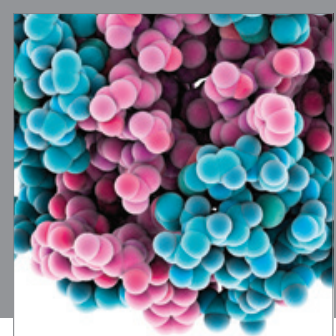

Journal of
Diabetes Research

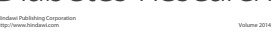

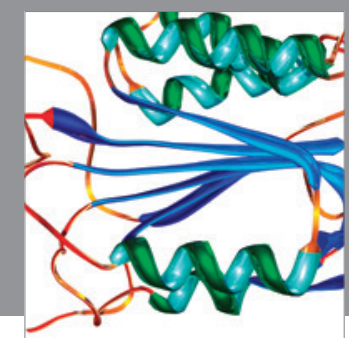

Disease Markers
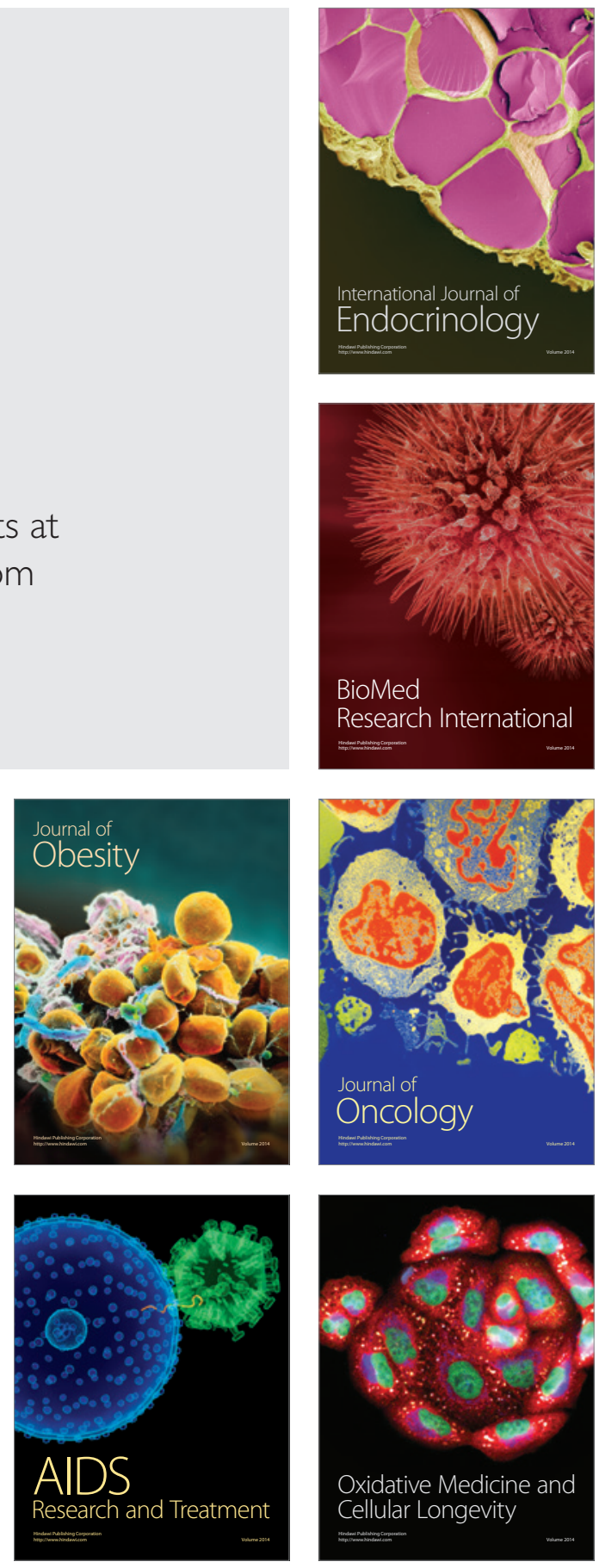